\title{
Assessment of Bacteriological Load of Meat Contact Surfaces and Practices of Butcher Shop Workers
}

\author{
Jyoti Pawan Chutia ${ }^{1 *}$, Poznur Hussain ${ }^{1}$, Sarat Sonowal ${ }^{1}$, Durlav Prasad Bora ${ }^{2}$, \\ Razibuddin Ahmed Hazarika ${ }^{1}$ and Aditya Baruah ${ }^{1}$
}

\author{
${ }^{I}$ Department of Veterinary Public Health, ${ }^{2}$ Department of Veterinary Microbiology, College \\ of Veterinary Science, Assam Agricultural University, Khanapara, Assam, India
}

*Corresponding author

\begin{tabular}{|l|}
\hline Ke y w o r d s \\
$\begin{array}{l}\text { Bacteriological, } \\
\text { Butcher shop, Food } \\
\text { safety, TVC, } \\
\text { Hygiene }\end{array}$ \\
\hline Article Info \\
\hline $\begin{array}{l}\text { Accepted: } \\
\text { 12 December } 2018 \\
\text { Available Online: } \\
\text { 10 January } 2019\end{array}$ \\
\hline
\end{tabular}

\section{A B S T R A C T}

Food safety has been a matter of great concern and of public health significance in particular when the environment in which the food is handled and heavily contaminated. Foods of animal origin tend to deteriorate more rapidly and become an important vehicle of food borne infections and the consequent illnesses that lead to high mortality and economic loss. The present investigation was carried out to assess the bacteriological load of meat contact surfaces and the management practices in 36 randomly selected butcher shops in and around Guwahati city. Information on knowledge, attitude and practice of butcher shop workers were gathered by interview method using a structured questionnaire. Out of 36 butcher shop workers interviewed, all the workers were recorded to be male with age ranging between $18-60$ years, $80.56 \%$ received primary school education, $36.11 \%$ received formal training on hygienic meat handling, $16.67 \%$ did not use protective clothes and $58.33 \%$ did not cover their hair during work. In addition, $58.33 \%$ of the butchers handled money while serving meat and $77.78 \%$ wore rings. Bacterial load was assessed by serial dilution method using standard procedure. A total of 216 of swab samples from six different sources (butcher's knives, meat chopping tables, worker's hands, weighing pans, meat wood cutting blocks and water used for cleaning of meat) were collected for enumeration of TVC. The mean values of TVC were found to be highest on swab samples collected from meat cutting blocks $\left(6.12 \pm 0.01 \log C F U / \mathrm{cm}^{2}\right)$ and lowest on water $(5.12 \pm 0.08 \mathrm{CFU} / \mathrm{ml})$. The present investigation indicated poor level of personnel hygiene and poor sanitation in butcher shops. Thus policies, regulations and procedures for hygienic meat handling need to be adhered and enforced by relevant authorities in order to ensure wholesome and safe meat for human consumption.

\section{Introduction}

Food safety is a matter of great concern and of public health importance in particular when the environment in which the food is handled is heavily contaminated (Soyiri et al., 2008). Under tropical conditions, food of animal origin tends to deteriorate more rapidly and become an important vehicle (Akinro et al., 2009) of food borne infections and the consequent illnesses that lead to high mortality and economic loss (Adak et al., 2005). It has been reported that Gram negative bacteria accounts for approximately 
$69 \%$ of the cases of bacterial food-borne disease (Clarence et al., 2009) with the coliform being the most frequently identified group on meat which include Citrobacter freundii, Escherichia coli and less frequently of the genera Klebsiella, Salmonella, Vibrio cholera, Shigella sonnie and Proteus spp. E. coli and Staphylococcus aureus are normal flora in human and animals and their presence in foods are indications of excessive human handling (Turtura, 1991; Elmossadam, 2003).

The possible sources of these bacteria are skin of the animal, the meat contact surfaces (tables, logs, hooks, balances and knives) and the clothes and hands of personnel involved in the meat processing operation. Butcher shop workers are the largest contamination source and the workers who do not follow sanitary practices, contaminate food that they touch which results spoilage due to microorganisms. Workers come in contact with these micro-organisms may be transferred to food during processing, packaging, preparation and service by touching, breathing, coughing or sneezing (Cohen et al., 2007; Selvan et al., 2007; Biswas et al., 2011)

Therefore, in the prevention of meat contamination, personal hygiene plays an important role as there are as many as 200 different species of micro-organisms on a healthy human body (Featherstone, 2003).Several studies have now been conducted from various countries to assessed the bacterial load of meat contact surfaces and practices associated with food safety of butcher shop workers (Haileselassie et al., 2013; Nervy et al., 2011; Gurmu and Gebretinsae, 2013; Ntanga, 2013). However, there is dearth of report regarding the assessment of bacteriological load of meat contact surfaces and practices associated with food safety of butcher shop workers in India. Hence, the present study was carried out to assess the bacteriological load of meat contact surfaces and practices associated with food safety of butcher shop workers in and around Guwahati city.

\section{Materials and Methods}

\section{Study area}

The study was carried out in 36 randomly selected butcher shops located in 6 markets in and around Guwahati city (viz. Khanapara, Sixmile, Beltola, Ganeshguri, Uzanbazar and Lakhora).

\section{Study design}

A descriptive survey design was used to answer questions concerning the current status of food hygiene and sanitation practiced in butcher shops. Hygiene and sanitation was determined by the use of structured interview and through direct observations of the hygienic status and practices by butcher shop workers. Bacteriological analysis of swabs taken from meat contact surfaces with the intention of colony count and to supplement the sanitary survey. The target population constituted the butchers of randomly selected butcher shops in and around the city.

\section{Questionnaire survey}

A total of 36 randomly selected butcher shop workers were interviewed by questionnaire for meat handling practices. The observations recorded were educational status, exposure and frequency of training, if they wore apron, hair cover, and jewelry; if they handle money; how often they wash their hands; frequency of health checkup; availability and accessibility to clean and safe water.

\section{Sample collection}

Sample swabs were randomly collected aseptically from butcher's knives, meat 
chopping tables, worker's hands, weighing pans and meat wood cutting blocks. An area of $1 \mathrm{~cm}^{2}$ was used for swabbing and moistened sterile cotton wool swabs were used for this purpose.

The swabs were transferred to the respective capped sterile tubes containing $10 \mathrm{ml}$ normal saline and labeled. Samples were packed in cool box and transported to laboratory for microbiological analysis. Water sample was collected directly with sterile bottles, labelled, placed in cool box with ice pack then transported to laboratory for microbiological analysis.

\section{Enumeration of total viable count}

The samples were taken using sterile pipette and further diluted serially (10 folds dilution) into 10 test tubes.

The diluents were mixed well and then one millilitre of diluted sample were poured into various sterile petri dishes and covered with 20 millilitres of sterile nutrient agar. All samples inoculated with nutrient agar were incubated at $37^{\circ} \mathrm{C}$ for 24 hours in order to get total viable count (TVC).

\section{Data analysis}

Data on bacteriological quality of meat contact surfaces were summarized using descriptive statistics; means, frequencies and percentages.

TVC were represented as log colony-forming unit per gram (CFU/g) and means were calculated and presented in tabular form. To examine any statistical significant difference of the means between and within the six samples, one way analysis of variance (ANOVA) was used. Statistical significance was set at $\mathrm{p}<0.05$ using the computer software statistical package for the social sciences (SPSS).

\section{Results and Discussion}

\section{Age and sex distribution of respondents}

Out of the 36 randomly selected butchers shop workers interviewed, all the respondents were males (Table 1), which are in agreement with Adzitey et al., (2011), who reported that the butchering activity is more dominated by the men who are more energetic as the butchering business requires much physical strength.

Out of the 36 randomly selected butchers shop workers $47.22 \%$ of workers had an age between $>18-30$ years followed by $>30-40$ years $(27.78 \%)$ and $>40-60$ years $(13.89 \%)$. Moreover, workers with age <18years $(11.11 \%)$ were also recorded who were primarily involved in cleaning activities. Findings from this study are different from what was reported in Tanzania by Ntanga (2013) who found $45 \%$ of workers had an age between 18- 30 years followed by 31-40 years $(52.50 \%)$ and $41-60$ years $(2.50 \%)$.

\section{Educational status, training and practices regarding the hygienic status of the butchers}

The level of education and training of meat handlers about the basic concept and requirements of personal hygiene and its environment plays an important part in safeguarding the safety of products to consumers (Ntanga, 2013). The present study revealed that, $80.56 \%$ of the respondents had primary school education, $11.11 \%$ had secondary education, and $8.33 \%$ of them don't have any education (Table 2). Findings of this study are different that of Gurmu and Gebretinsae (2013), who revealed that out of 24 butcher shop workers were interviewed for their knowledge on meat hygiene, $41.70 \%$ were illiterate. Moreover in our study $63.89 \%$ of the respondents did not take any training 
regarding meat hygiene and handling practices which are in agreement with Gurmu and Gebretinsae (2013), who reported that out of 24 butcher shop workers $58.3 \%$ of the respondents did not take training regarding meat and butcher area hygiene. Butcher shops workers having lower level of education or no education without any training regarding meat handling and hygiene pay no attention to the hygienic standards and as a result contribute immensely to bacterial contamination.

Present study revealed that $16.67 \%$ of the workers did not use protective clothes and $58.33 \%$ did not cover their hair. Similar to our findings Haileselassie et al., (2013) have also reported that out of 71 butcher shop workers interviewed, $11.30 \%$ did not use protective clothes and $50.70 \%$ did not cover their hair. Practices like wearing unhygienic dirty clothes and uncovered hairs during operation in the butcher shops could lead to cross contamination with pathogenic microbes making the meat unsafe to the consumer. Thus, the practice of wearing protective clothes before and after sales of meat is important since it helps to reduce the burden of contaminants in meat (Ntanga, 2013).

This study showed that $13.89 \%$ and $41.67 \%$ workers had no habits of washing their hands with water and soap before and after sale of meat respectively, which contribute to contamination of meat. This is well supported with the reports of Ntanga (2013), who found $12.50 \%$ and $37.50 \%$ of workers were not washing their hand with water and soap before and after sale of meat respectively. However, Bell and Hathaway (1996) reported that a $44^{\circ} \mathrm{C}$ water hand rinse removed $90 \%$ of microbial contamination from workers hands. Thus, adopting hygienic practice of washing hand with lukewarm water and soap before and after sale of meat could reduce microbial contamination of meat ensuring safe meat products to the consumer.
According to the present study $58.33 \%$ of workers handled money with bare hands during sale of meat which are in agreement with Haileselassie et al., (2013), who reported that, out of 71 butcher shop workers interviewed $47.90 \%$ of them handled money while serving food. Money in the form of paper currency is widely used in meat trade, with lower - denomination notes receiving the most handling because they are exchanged many times, and provides a large surface area as a breeding ground for pathogens (Gads by, 1998). This kind of paper currency becomes the source of microbial contamination and when handled with bare hands by butcher shops workers contaminate the hand surface which in turn contaminates the meat making the meat unsafe for consumers. Thus, cashier system could be adopted to prevent such contamination. This study also revealed that $77.78 \%$ of the workers had worn jewellery during butchering operation. This finding is in agreement with the study conducted by Haileselassie et al., (2013), who found $78.90 \%$ of the butcher shop workers had worn jewellery during butchering operation. Jewellery during butchering operation can become favourable breeding site for microorganisms and in turn source of contamination of meat. In the present study, meat contact surface associated with wearing jewellery reveals high microbial load. Thus, adoption of practice of not wearing any kind of jewellery during butchery operation can prevent contamination of meat.

A regular health checkup of butcher shops workers is important since it helps in the control and prevention of transmission of food borne diseases to the consumer. However in this study $11.11 \%$ workers had a routine health check-up after every 3 months and $5.56 \%$ had a routine health check-up after every 6 months and $83.33 \%$ never had any health check-up. The findings from this study are different from that of Ntanga 
(2013), who reported that all workers in retail meat outlets of Morogoro municipality, Tanzania had a routine medical examination and regularly inspected by Health Officers. The high percentage of butcher shops workers who never had any heath checkup might be attributed to the lack of knowledge, poor economic background and lack of visit by the health officers.

In the present study, out of 36 butcher shop workers interviewed $61.11 \%$ of workers used soap and water for daily cleaning of their shops. Despite of this practice most of the shops had poor hygienic condition. This might be attributed to the lack of knowledge of butcherman regarding disinfection and sanitizing practice (Ali et al., 2010). Thus, imparting training on use of disinfecting and sanitizing agents for daily cleaning of butcher shops could elevate the hygienic status.

Meat wood cutting blocks are commonly used in most of the butcher shops even though it harbours microorganisms due to absorptive nature. In the present study $77.78 \%$ of the meat wood cutting blocks used in the selected 36 burcher shops were in poor hygienic condition. This finding agrees with the report of Ntanga (2013), who reported that $73.70 \%$ of the wood cutting blocks present in the shops of Tanzania were in poor hygienic condition. Meat wood cutting blocks are commonly used in the butcher shops. Due to continuous used of meat wood cutting blocks for cutting meats, the surface may become absorptive in nature providing favourable environment for growth and multiplication of microorganism. Proper cleaning and washing of wood cutting blocks with appropriate disinfectants is the utmost important to ensure good hygienic condition.

Flies play very important roles in transmission of various disease causing agents with potential to cases such as enteric infections. Flies feed on various waste products present in the environment having high microbial load. Meat in butcher shops if left uncovered to easily be contaminated with potential disease causing agents when the flies feed on meats. In the present study, $44.44 \%$ of the workers used glass window and daily cleaning of the shops to prevent flies. However, $55.56 \%$ used some other methods such as fly repellent spray. Similar reports were also reported by Ntanga (2013), who found that $50.00 \%$ of the workers used glass windows and cleaned their shops daily and the remaining $50.00 \%$ of worker used glass window and pyrethrins pesticides to prevent flies in the butcher shops. The present study revealed that a higher percentage of butcher shops worker used fly repellent spray to control flies. This practice can be hazardous to human health as chemical present in the fly repellent spray may remain as residue in meat. Also it was observed that some of the butcher shop workers used to cover their meat with dirty clothes to prevent flies which may causes contamination of the meat. Thus, used of glass window and daily cleaning of shops as hygienic practices should be encourage to control flies.

About $75.00 \%$ butcher shops had no refrigerators in their shops. Similar observation was also made by Ntanga, (2010) who reported that $72.50 \%$ of the retail shops had no refrigerators. Cool storage facilities are important in keeping the meat fresh and safe for a long period of time. However, present study revealed that higher percentage of shops didn't have any cool storage facilities for meat. Thus, a common practice was to transfer the remaining meat from one shop to another where refrigerators were available and meat from different butcher shops were mixed together. This might lead to transfer of microbes from one butcher shops to another if hygienic condition is not well observed. Moreover, $38.89 \%$ meat sellers in 
the present study mixed previous day meat with the fresh meat. Such malpractices may lead to contamination of fresh meat. Hence it should be strictly monitor by governmental authority to provide save food to the consumer.

\section{Enumeration of total viable count}

The results of this study showed that the highest log mean value of TVC were observed on meat wood cutting blocks $\left(6.12 \pm 0.01 \mathrm{CFU} / \mathrm{cm}^{2}\right)$ followed by butcher's knives $\left(6.11 \pm 0.01 \mathrm{CFU} / \mathrm{cm}^{2}\right)$, meat chopping tables $\left(5.83 \pm 0.02 \mathrm{CFU} / \mathrm{cm}^{2}\right)$, worker's hands $\left(5.83 \pm 0.01 \mathrm{CFU} / \mathrm{cm}^{2}\right)$, weighing pans $\left(5.69 \pm 0.03 \mathrm{CFU} / \mathrm{cm}^{2}\right)$ and lowest mean values were observed on water $(5.12 \pm 0.08 \mathrm{CFU} / \mathrm{ml})$ (Table 3).

The high microbial load obtained from meat wood cutting blocksis an indication of the ineffectiveness of the method used in cleaning the blocks, which are usually washed with water only. Moreover, wooden blocks are used for cutting the carcass into bits and chopping or mincing of meat in the shops. Wood being absorptive in nature may absorb blood/drip from the meat which serves as an ideal medium for growth and multiplication of food borne microorganisms. All of these factors could also have resulted in a higher load on the wooden block used in the meat shops.

The number obtained from meat wood cutting blocks, butcher's knives, meat chopping tables, weighing pans in this study is almost similar to values of obtained by Ntanga (2013) who reported total viable count of $6.14 \pm 1.21,6.16 \pm 1.25,5.88 \pm 1.53,5.77 \pm 1.49$ $\mathrm{CFU} / \mathrm{cm}^{2}$ for meat wood cutting blocks, butcher's knives, meat chopping tables, weighing pans respectively in Tanzania. The higher levels of TVC in handling equipments in the butcher shops are indication of inadequate cleaning and poor disinfection. The high microbial load on the knife is an indication of inadequate cleaning and poor or absence of sterilization, continuous use of a single knife despite contact with dirty or contaminated surfaces and lack of separation between clean and dirty processes. The total mean bacterial load $5.83 \pm 0.01 \mathrm{CFU} / \mathrm{cm}^{2}$ obtained from the worker's hands in this study was lower than the value reported by Gurmu and Gebretinsae (2013) which was 6.15 $\mathrm{CFU} / \mathrm{cm}^{2}$ from worker's hands after processing of the meat from various butcher shops of Mekelle city, Ethiopia.

This may be due to poor level of personnel hygiene and the personnel working in the butcher shops did not apply hygienic practices like wearing meat handling gloves which is mainly due to lack of knowledge.

Moreover the values obtained on wood cutting blocks, knives and weighing balance were lower compared to those reported by Bhandare et al., (2009) with the mean values of $7.33 \pm 0.20,6.45 \pm 0.26$ and $5.93 \pm 0.31 \mathrm{logs}$ $\mathrm{CFU} / \mathrm{cm}^{2}$ in wooden log, knives and weighing balances respectively. The total mean bacterial load $5.12 \pm 0.08 \mathrm{CFU} / \mathrm{ml}$ obtained from the water in this study is similar to values of obtained by Bhandare et al., (2009) which is $5.18 \pm 0.23 \mathrm{CFU} / \mathrm{ml}$ from water from different traditional meat shops in Mumbai, India.

Based on the bacterial load on different surfaces in the butcher shops, meat could be contaminated by contact with contaminated surfaces and equipments in the butcher shops to pose public health hazards. Thus to safeguard the public against the risks of food borne bacterial infections, there is need to educate and advocate for practicing good sanitation and meat handling techniques in the butcher shops. 
Table.1 Age distribution of butcher shop workers $(n=36)$

\begin{tabular}{|c|c|}
\hline Age (Years) & Number of respondents (\%) \\
\hline$<\mathbf{1 8}$ & $4(11.11)$ \\
\hline$>\mathbf{1 8 - 3 0}$ & $17(47.22)$ \\
\hline$>\mathbf{3 0 - 4 0}$ & $10(27.78)$ \\
\hline$>\mathbf{4 0}-\mathbf{6 0}$ & $5(13.89)$ \\
\hline
\end{tabular}

Table.2 Questionnaire survey on educational status, training and practices regarding the hygienic status of the butchers $(n=36)$

\begin{tabular}{|c|c|c|c|}
\hline Observation & Social value & Number of respondents & Percent \\
\hline \multirow[t]{3}{*}{ Educational status } & Primary school education & 29 & 80.56 \\
\hline & Secondary school education & 4 & 11.11 \\
\hline & No education & 3 & 8.33 \\
\hline \multirow[t]{2}{*}{ Training } & Yes & 13 & 36.11 \\
\hline & No & 23 & 63.89 \\
\hline \multirow[t]{2}{*}{ Apron } & Used & 30 & 83.33 \\
\hline & Not used & 6 & 16.67 \\
\hline \multirow[t]{2}{*}{ Hair } & Covered & 15 & 41.67 \\
\hline & Not covered & 21 & 58.33 \\
\hline \multirow{2}{*}{$\begin{array}{l}\text { Washing of hand before } \\
\text { cutting of meat }\end{array}$} & Yes & 31 & 86.11 \\
\hline & No & 5 & 13.89 \\
\hline \multirow{2}{*}{$\begin{array}{l}\text { Washing of hand after } \\
\text { sale of meat }\end{array}$} & Yes & 21 & 58.33 \\
\hline & No & 15 & 41.67 \\
\hline \multirow{2}{*}{ Handling of money } & Butcher (with bare hands) & 21 & 58.33 \\
\hline & Cashier & 15 & 41.67 \\
\hline \multirow[t]{2}{*}{ Jewellery } & Worn & 28 & 77.78 \\
\hline & Not worn & 8 & 22.22 \\
\hline \multirow{2}{*}{$\begin{array}{l}\text { Daily cleaning for } \\
\text { butcher shops by water } \\
\text { and soap }\end{array}$} & Yes & 22 & 61.11 \\
\hline & No & 14 & 38.89 \\
\hline \multirow{2}{*}{$\begin{array}{l}\text { Condition of meat wood } \\
\text { cutting blocks }\end{array}$} & Good & 8 & 22.22 \\
\hline & Poor & 28 & 77.78 \\
\hline \multirow{2}{*}{$\begin{array}{l}\text { Method used for control } \\
\text { of flies }\end{array}$} & Glass window & 16 & 44.44 \\
\hline & Others & 20 & 55.56 \\
\hline \multirow[t]{2}{*}{ Sale of fresh meat } & Yes & 22 & 61.11 \\
\hline & No & 14 & 38.89 \\
\hline \multirow[t]{2}{*}{ Storage of meat } & $\begin{array}{l}\text { Use of refrigerators in own } \\
\text { butcher shop }\end{array}$ & 9 & 25.00 \\
\hline & $\begin{array}{l}\text { Use of refrigerators in others } \\
\text { butcher shop }\end{array}$ & 27 & 75.00 \\
\hline \multirow{3}{*}{$\begin{array}{l}\text { Health check up of } \\
\text { butchers }\end{array}$} & In every 3 months intervals & 4 & 11.11 \\
\hline & In every 6 months intervals & 2 & 5.56 \\
\hline & Never & 30 & 83.33 \\
\hline
\end{tabular}


Table.3 Mean values for TVC $\left(\log \mathrm{CFU} / \mathrm{cm}^{2}\right.$ or $\left.\mathrm{ml}\right)$ of the meat contact surface samples from butcher shops

\begin{tabular}{|l|l|}
\hline Sample types & TVC $($ Mean \pm SE) \\
\hline Butcher's knives & $6.11 \pm 0.01^{\mathrm{a}}$ \\
\hline Meat wood cutting blocks & $6.12 \pm 0.01^{\mathrm{a}}$ \\
\hline Meat chopping tables & $5.83 \pm 0.02^{\mathrm{b}}$ \\
\hline Weighing pans & $5.69 \pm 0.03^{\mathrm{b}}$ \\
\hline Worker's hands & $5.83 \pm 0.01^{\mathrm{b}}$ \\
\hline Water & $5.12 \pm 0.08^{\mathrm{c}}$ \\
\hline Aggregate & $5.78 \pm 0.03$ \\
\hline
\end{tabular}

Least squares Means Differences, Tukey's honestly significant difference (HSD) for $\alpha=0.050$ $\mathrm{Q}=2.88$ Rows bearing different superscripts differ significantly at $\mathrm{p}<0.05$

In conclusion this study showed that all the meat contact surfaces in the butcher shops had high bacterial load. This may be due to the low level of knowledge of the butcher shops worker regarding hygienic meat handling. This may contribute towards a high incidence of food associated illness through cross contamination of different food products. In order to avoid cross contamination of carcasses in slaughter areas, it is suggested to clean and sanitize the most contaminating points such as floors, walls, evisceration platforms, wooden logs etc. Moreover, it is important to provide education to the butcher shop workers regarding proper maintenance of hygiene and sanitation.

Policies, regulations and guidelines regarding food safety at all levels along the production chain should be adhered to and enforced so as to produce safe and wholesome meat. The use of wood cutting blocks in retail meat outlets should be discouraged since it harbours microorganisms due to its porous in nature which allow water to infiltrate and accumulate organic matter. Establishment of control measures depending upon the prevailing conditions with an appropriate monitoring system is necessary so that consumers get safe and wholesome meat.

\section{Acknowledgement}

The authors are thankful to the Department of Veterinary science, Assam Agricultural University, Khanapara-781022 to carry out the research work.

\section{References}

Adak, G.K., Meakins, S.M., Yip, H., Lopman, B.A. and O'Brien, S.J. 2005. Disease risks from foods, England and Wales, 1996-2000. Emerging Infectious Diseases.11(3). pp. 365-72.

Adzitey, F., Teye, G.A. and Dinko, M.M. 2011. Pre and post-slaughter animal handling by butchers in the Bawku Municipality of the Upper East Region of Ghana. Livestock Research for Rural Development. 23(39).

Akinro, A.O., Ologunagba, I.B. and Yahaya, O. 2009. Environmental Implications of unhygienic operation of a city abattoir in Akure, Western Nigeria. Journal of Engineering and Applied Sciences.4(9): 60-63.

Ali, N.H., Farooqui, A., Khan, A., Khan, A.Y. and Kazmi, S.U. (2010). Microbial contamination of raw meat and its environment in retail shops in Karachi, Pakistan. Journal of Infection in 
Developing Countries. 4(6): 382-388.

Bell, R.G. and Hathaway, S.C. (1996). The hygienic efficiency of conventional and inverted lamb dressing systems. Journal of Applied Bacteriology. 81(3): 225-234.

Bhandare, S.G., Paturkar, A.M., Waskar, V.S. and Zende, R.J. (2009). Bacteriological screening of environmental sources of contamination in an abattoir and the meat shops in Mumbai, India. Asian Journal of Food and Agro-Industry. 2(03): 280-290.

Biswas, A.K., Kondaiah, A.K., Anjaneyulu, A.S. and Mandal, P.K. (2011). Causes, concerns, consequences and control of microbial contaminants in meat. International Journal of Meat Science. 1: 27-35.

Clarence, S., Obinna, C. and Shalom, N.C. (2009). Assessment of bacteriological quality of ready to eat food (Meat pie) in Benin City metropolis, Nigeria. African Journal of Microbiology Research. 3: 390-395.

Cohen, N., Ennaji, H., Hassar, M. and Karib, H. (2007). The bacterial quality of red meat and offal in Casanblanca (Morocco). Molecular Nutrition and Food Research.50: 557-562.

Elmossadam, K. (2003). Attachment of Listeria microcytrogeneto stainless steel surface of various temperature and $\mathrm{pH}$ values. Journal of food science. 53: 103111.

Featherstone, S. (2003). Food hygiene not for sissies. South African Food review. Journal for Food and Beverage Manufactures. 30: 49.

Gadsby, P. (1998). Filthy lucre-money contaminated with bacteria. Discover. 19: 76.

Gurmu, E.B. and Gebretinsae, H. (2013). Assessment of bacteriological quality of meat contact surfaces in selected butcher shops of Mekelle city, Ethiopia. Journal of Environmental and Occupational Science. 2(2):61-66.

Haileselassie, M., Taddele, M., Adhana, K. and Kalayou, S. (2013). Food safety knowledge and practices of abattoir and butchery shops and the microbial profile of meat in Mekelle City, Ethiopia. Asian Pacific Journal of Tropical Biomedicine.3(5): 407-412.

Ntanga, P.D. (2013). Assessment of microbial contamination in beef from abattoir to retail meat outlets in Morogoro municipality, Tanzania. M.Sc. thesis, Sokoine University of Agriculture, Mororogo, Tanzania.

Selvan, P., Babu, R.N., Sureshkumar, S. and Venkataramanujan, V. (2007). Microbial quality of retail meat products available in Chennai city. American Journal of Food Technology. 2: 55-59.

Soyiri, I.N., Agbogli, H.K. and Dongdem, J.T. 2008.A Pilot microbial assessment of beef in the Ashaima Market, a suburb of Accra Ghana. African Journal of Food, Agriculture, Nutrition and Development.8(1): 91-103.

Turtura, G.C. (1991). Enterobacteriaceae and other Gram negative bacteria in slaughtered poultry. Microbiology Ailments and Nutrition. 9: 139-146.

\section{How to cite this article:}

JyotiPawan Chutia, Poznur Hussain, Sarat Sonowal, Durlav Prasad Bora, Razibuddin Ahmed Hazarika and Aditya Baruah. 2019. Assessment of Bacteriological Load of Meat Contact Surfaces and Practices of Butcher Shop Workers. Int.J.Curr.Microbiol.App.Sci. 8(01): 18391847. doi: https://doi.org/10.20546/ijcmas.2019.801.194 